\title{
Darüşşifalar Bağlamında Kitabeler, Vakıf Kayıtları ve Tıp Tarihi Açısından Önemleri - Anadolu Selçuklu Darüşşifaları Özelinde*
}

\author{
Importance of inscriptions and waqf registrations of dar al-shifas (hospitals) from Anatolian Seljuks era in respect of \\ history of medicine
}

\section{Ahmet Acıduman}

'Ankara Üniversitesi Tip Fakültesi Tıp Tarihive Etik Anabilim Dalı

*Bu yazı 27 Mayıs 2010 tarihinde Ankara Üniversitesi Tıp Fakültesi, Tıp Tarihi ve Etik Anabilim Dalı'nda "Konukevi Çevresi Seminerleri" çerçevesinde sunulan "Darüşsifalar bağlamında kitabeler, vakıf kayıtları ve tıp tarihi açısından önemleri" bașıklı konușma temel alınarak hazırlanmıştır.
Başvuru tarihi: 18.06.2010 • Kabul tarihi: 25.10.2010

İletişim

Doç. Dr. Ahmet Acıduman

Ankara Üniversitesi Tıp Fakültesi Tıp Tarihi ve Etik Anabilim Dalı Morfoloji Binası 2.Kat 06100 Sihhiye / ANKARA

Tel : : $03123103010 / 370$

E-Posta Adresi : aciduman@medicine.ankara.edu.tr

Darüşşifalar Türk-i̇slâm vakıf kültürü içerisinde önde gelen sosyal yardım kuruluşlarından birisidir. Tıp mesleğinin uygulanmasına yönelik özel mimari anlayış içeren yapıları ile toplumun sağlık gereksiniminin karşılanması için yapılan bu kuruluşlar, varlıklarını vakıfları ile korumuşlar ve sürdürmüşlerdir. Selçukluların özellikle Anadolu'da ortaya koyduğu darüşşifalar Türk tıp tarihi açısından önem taşımaktadırlar. Bunların içerisinde Anadolu Selçuklu Sultanı İzzeddin Keykâvus tarafından 1217 yılında yaptırılan Sivas Darüşşifası hakkında hem mimari, hem sanat tarihi, hem de Selçuklulardan günümüze ulaşan tek vakfiyeye sahip olması nedeniyle, tıp tarihi açısından pek çok araştırma yapılmış ve önemli bilgilere ulaşılmıştır. Vakfiyeler, tahrir ve evkaf defterleri, atama fermanları gibi yazılı belgeler binaları artık var olmayan ve yerleri bilinmeyen darüşsifalar ve medreseler gibi eserlerin varlığını bize haber vermektedirler. Bu konuya Kütahya hastanesi örnek olarak verilebilir. Anadolu Selçuklularından günümüze kalan darüşşifaların bazılarında kitabelerin de bulunması bu yapıların banilerini, yapım tarihlerini ve bu eserlerin mimarlarını da bize bildirmektedir. Sivas İzzeddin Keykâvus Darüssıhası vakfiyesinden başka kitabesi ile de önemli bir örnektir. Öte yandan kitabeler bize günümüzde ayakta olmayan darüşşifaların varlığını da kanıtlamaktadır. Buna örnek olarak Çankırı Cemaleddin Ferruh Darülafiyesi verilebilir. Vakıfların elindeki belgelerin tıp tarihi açısından taşıdığı önem tartışılmaz görünmektedir. Bu nedenle vakıf kayıtları özenle yeniden gözden geçirilmeli, yeni bulgular ışığında var olan bilgi ve bulgular değerlendirilmeli, gerekirse yeniden yorumlanmalı ve bilimsel ortamlarda bilim dünyasına sunulmalıdır. Bu amaçla yapılacak araştırmaların multidisipliner yaklaşımla ele alınması, vakıf uzmanları, sanat tarihçileri, mimarlar, tarihçiler ve tıp tarihçileri tarafından ortaklaşa yapılması daha doğru sonuçlara ulaşmamızı sağlayacaktır.

Anahtar Sözcükler: Darüşşifa, Hastane, Vakıf, Kitabe, Anadolu Selçuklu, Tıp Tarihi

Dar al-shifas (hospitals) were one of the eminent social aid foundations in Turkish-Islamic waqf culture. These foundations with their characteristic architectures for medical applications were established for health needs of society protected and survived their existence with their waqfs. Dar al-shifas that were particularly founded by Seljuks in Anatolia are important for Turkish history of medicine. Dar al-shifa of Sivas founded by Izz al-din Kaykavus in 1217 is an important example for architecture, history of art and history of medicine because of its unique deed of trust, so important knowledge was achieved by many researches. Written documents such as deeds of trust, notebooks of registration and assignment firmans let us know dar al-shifas and medressehs that their places are not known or their buildings do not exist any longer. Kutahya hospital is an example. Inscriptions of some dar al-shifas from Anatolian Seljuks inform us their founders, dates of constructions and architects. Sivas Izz al-din Kaykavus Dar al-shifa is an important example with its deed of trust and also its inscription. Inscriptions prove existence of dar al-shifas that their buildings are not at present, for example Cankırı Camal al-din Ferruh Dar al-shifa. Importance of documents in Directorate of Waqfs seems to be indisputable for history of medicine, so registration of waqfs should be carefully reviewed, present findings and knowledge should be evaluated in the light of new discoveries and reinterpreted when needed and should be presented to the world of science in scientific environments. Multidisciplinary researches by experts of waqf, historians of art, architects, historians and medical historians make us reach more precise results.

Key Words: Dar al-shifa, Hospital, Waqf, Inscription, Anatolian Seljuks, History of Medicine

Şifahane, bimaristan, maristan, darüssıhha, darülafiye, me'menülistirahe, darüttıb, darülmerza, şifaiyye, bimarhane, tımarhane olarak da adlandır1lan $(1,2)$ darüşşifalar Türk-İslâm vakıf kültürü içerisinde önde gelen sosyal yardım kuruluşlarından birisidir. Tıp mesleğinin uygulanmasına yönelik özel mimari anlayış içeren yapıları (3) ile de ayrıcalıklı bir yere sahiptir- 
ler. Türk kültürü açısından ele alındığında, Selçukluların ortaya koyduğu darüşşifalar, özellikle Anadolu'daki örnekleriyle, çok uzun süreler kuruluş amaçları ile ilgili görevlerini sürdürmüşlerdir. Toplumun sağlık gereksiniminin karşılanması için yapılan bu kuruluşlar, varlıklarını vakıfları ile korumuşlar ve sürdürmüşlerdir.

Var olan belgeler diğer İslâm ülkelerinde kurulan darüşşifalarda olduğu gibi, Selçuklu darüşşifalarında da hastaların zengin, fakir, din, dil ve ırk ayrımı yapilmaksızın tedavi edildiklerini ortaya koymaktadır. Bu hastanelerde ilaçlar ve yiyecekler hastalara ücretsiz verilirken, tedavileri de ücretsiz yapılırdı (1,4-6). Dinçer (7), darüşşifalardaki bu uygulamaların sağlık hizmetlerinde sosyalizasyonun ilk örneklerinden birisi olduğunu dile getirmektedir. Özellikle ruh hastalıklarının tedavisinin de darüşşifalarda yapıldığı, tedavi için müzikten ve telkinden yararlanıldığı görülmektedir $(1,5)$. Hastaneler aynı zamanda hasta yatağı başında pratik tıp eğitiminin de yapıldığı yerlerdir (13,8 ). Terzioğlu (5) hastanelerle ilgili bir çalışmasında ortaçağda kurulan İslâm hastanelerinin en önemli karakterinin laik kuruluşlar olduğunu, ortaçağ Hıristiyan hastanelerinde bakım yapan personelin dini kuruluş mensubu olmasına karşın, İslâm hastanelerinde bu kişilerin böyle olmadığını bildirmektedir. Terzioğlu'nun (5) vurguladığı bir başka önemli bulgu ise hastanelerin işlevlerine yönelik olarak, İslâm hastanelerinin hastaları tıbbî bilgilerle iyileştirmeye yönelik klinik özelliği taşıyan kuruluşlar olmasına karşılık, Hıristiyan hastanelerinin Rönesans'a kadar hastaların tedavi edilmeksizin, yalnızca ölene kadar tecrit edildikleri yer olmasıdır. Hastaneler arasındaki bir başka farklılık ise İslâm hastanelerinde çeşitli uzmanlık konularında hekimlerin çalışmasına karşılık, Hıristiyan hastanelerinde XV. yüzyıla kadar hekimlerin çalışmasının nadir görülen bir durum olmasıdır (5). Yinanç (9), Bayat (10) ve Terzioğlu (5) eldeki belgelere bakarak Türk-İslâm Hastanelerinde XIII. yüzyılda hekimlikte uzmanlığın başladığı görüşündedirler. Terzioğlu (5) yaptığı araştırmalar sonrası İspanya ve İtalya'da bazı hastanelerin yapımında Türk-İ̉lâm hastanelerinin örnek alındığını belirtmektedir. Mimarinin yanı sıra tıp okullarında okutulan kitaplar da Râzî, Ali ibn Abbâs ve İbn Sînầnın eserleridir. Terzioğlu (11) bir başka çalışmasında da Avrupa Üniversitelerindeki teorik ve pratik tıp eğitiminin ve yine hekimlik deontolojisi esaslarının Selçuklu dönemindeki tıp eğitimi sisteminden etkilenmiş olduğunu karşılaştırarak göstermektedir.

\section{Darüşşifalar, Vakıflar, Kitabeler}

Darüşşifaların varlıklarını koruyup sürdürmeleri için gerekli en önemli koşullardan birisi bu kuruluşların vakıflarıdır. Vakıf-darüşşifa birlikteliği açısından ele alındığında "vakıf" kelime olarak "durdurma, durmasinı sağlama, alıkoyma” anlamlarını taşımaktadır (12). Yine "bir hizmetin yerine getirilmesi amaciyla, bir kimsenin belli koşullar ve resmi yollarla parasını ya da mülkünü bağışlaması." ve "bu yolla bağışlanan mal, mülk, para; bu amaçla oluşturulan kuruluş" anlamlarına gelmektedir (13). Darüşşifalar okul, cami, hamam vb. gibi "vakf-1 ale-l 'âmme"dir (12). Yani kamu yararına yapılan, herkesin yararlanabildiği vakıflardandır. Vakıf kuruluşunun "vâkıf"1 (kurucusu) tarafindan belirlenen, o kuruluşun çalışma şeklini, yönetimini, kuruluşun amaç ve hizmetlerini, gelirlerini, giderlerini, kuruluşta çalışanların niteliklerini, alacakları ücretleri açıklayan yazılı belgelere de "vakfiye" (bir vakfin şartlarını bildiren resmi senet) ya da "vakıf-nâme" denir (12). Bu belgeler vakıf kuruluşlarının yönetmeliği niteliğinde olduğundan, özellikle tıp tarihimiz açısından da önemli bir yer tutan darüşşifaların hizmet verdikleri sürece onların işleyişleri, kuruluşları, kadroları ve çalışanların ücretlendirilmeleri açısından çok önemli tarihsel belgelerdir.

Türk Dil Kurumu Türkçe Sözlük (14) "Kitabe"nin kelime anlamını "taş, mermer vb. gibi sert cisim üzerindeki oyma veya kabartma yazı, tarih, yazıt" olarak vermektedir. Fermanlar, antlaşmalar, bir yapının yapılıs taribi, ne amaçla ve kimin tarafindan yaptırildu$\breve{g}$, kanunlar, Kur-an'dan alınmış ayetler ve hadislerin yazıldığ 1 kitabeler, dönemin şairlerinden birisinin eseri yaptırana sunduğu manzume beğenilirse, binanın girişinde, görünür bir yere ve genellikle mermer üzerine kazdırılarak yerleştirilirdi. Kitabeler genellikle ebced hesabıyla yapilış tarihini de gösterirdi. Çeşme, han, hamam, kütüphane, saray, kervansaray, imarethane, medrese, cami, mescit vb. kurumların kitabeleri manzum olurdu. Bunun dışında mensur kitabelere de rastlanırdı. Kitabelerin yazısı kûfi, nesih ve seyrek olarak taliktir (15). Kitabeler de vakıf kayıtları gibi bize darüşşifaların varlığını haber veren önemli kayıtlardandır.

Bayram (16) Anadolu Selçuklu Devleti'nin 1243 yilındaki Kösedağ savaşı ve yenilgisi sonrası Moğol egemenliği altına girmesi nedeniyle, Selçuklu devlet adamları, emirleri ya da zenginlerinin, Moğol yöneticileri tarafından mallarının ve servetlerinin müsadere edilmesini önlemek amacıyla vakıf müesseseleri kurduklarını ve bu nedenle XIII. yüzyılın ikinci yarısının Anadolu'da vakıf müesseselerinin en çok kurulduğu bir dönem olduğu tespitini yapmaktadır. Bu saptamaya göre değerlendirildiğinde Kastamonu Ali bin Pervâne Darüşşifası'nın 1272 yllinda, Tokat Muineddin Pervâne Darüşşifası'nın -1277 yılında ve Amasya Anber bin Abdullah Darüşşifası'nın da 1308 yılında kurulduğu görülmektedir. Bununla birlikte kurucusu İlhanlı hükümdarının eşi Yıldız Hatun'un kölelerinden Anber bin Abdullah olan Amasya'daki darüşşifanın, bu saptamanın dışında tutulabileceği görülmektedir.

\section{Anadolu Selçuklu Darüşşifaları}

Varlığı kesin olarak bilinen (ilk yedi sıradaki) ya da halen var olmasa da varlığı kanttlanabilen (sonraki dört) darüşşifalar şöyle sıralanmaktadır: 
1. Kayseri, Gevher Nesibe Tip Medresesi ve Mâristânı (1206),

2. Sivas, İzzeddîn Keykâvus Dârüssihası (1217),

3. Divriği, Turan Melek Dârüşşifâsı (1228),

4. Çankırı, Cemâleddin Ferruh Dârülâfiyesi (1235),

5. Kastamonu, Ali bin Süleyman Mâristânı (1272),

6. Tokat, Mu'înüddîn Süleyman Dârüşşifâsı (1255-1275 arası),

7. Amasya, Anber bin Abdullah Dârüşşifâsı (1308/9),

8. Mardin, Necmeddîn İlgazi Mâristânı (1108-1122 arasi) $(1,2,17)$,

9. Konya Darüşşifası (Maristan-ı Atik) (XII. yy. sonu XIII. yy. başı),

10. Konya Alâeddin Darüşşifası (12191237/38),

11. Aksaray Darüşşifası (XIII. yy) $(2,17)$.

Öte yanda bazı kaynaklarda adı geçmekle birlikte üzerinde araştırma yapılması gereken darüşşifalar ise şunlardır:

1. Silvan Darüşşifası (1176/77-1184/85),

2. Eski Malatya Darüşşifası (XIII. yy. ortasi),

3. Akşehir Darüşşifası (XII. yy. sonu XIII. yy başı),

4. Erzincan Darüşşifası (?),

5. Kastamonu Atabey Darüşşifası (127075)

6. Kütahya Darüşşifası (XIII. yy. ikinci çeyreği) $(1,18)$,

7. Sivas Şehzadeler Darüşşifası (?) (1),

8. Harput Darüşşifası (19-21),

9. Kars Darüşşifası (XII. yy) $(21,22)$.

Anadolu'da kurulmuş olan Selçuklu darüşşifaları içerisinde kuruluş vakfiyesi günümüze ulaşan tek örnek Sivas Darüşşfası'dır ve bu özelliği nedeniyle de oldukça ayrıcalıklı bir yere sahiptir. Anadolu Selçuklu Sultanı İzzeddin Keykâvus tarafindan 1217 yılında yaptırılan Sivas Darüşşifası hakkında hem mimari, hem sanat tarihi, hem de Selçuklulardan günümüze ulaşan tek vakfiyeye sahip olması nedeniyle, tıp tarihi açısından pek çok araştırma yapılmıştır (10). Ünver (23) "işte bu vakfiye ile Selçuklu hastanelerinin umum hastalara mahsus bir yurd olduğunu ve diğerlerinin bu şartlar dahilinde idame edildiğini öğreniyoruz" demektedir. Bayat (10) Anadolu Selçuklu Devleti'nin kısa ömrü içinde çok sayıda inşa edilmiş hastanelerin kadro, çalışma düzeni, eğitimi, yönetimi, vakıfları, hekimleri hakkında doğrudan bilgi sahibi olunabilecek kaynağın yok denecek kadar az olduğunu vurguladıktan sonra, Sivas Darüşşifası vakfiyenin tıp tarihi açısından önemi konusunda şunları söylemektedir:

"Elimizdeki bu vakfiyeden anlaşılıyor ki, Selçuklu Devri hastahanelerinde dahili, göz ve cerrahi hastalıklar tedavi ediliyor [du], ihtisas sahibi olarak cerrah, kehhal (göz hastalıkları uzmanı) ve genel hastalıklar mütehassısları çalışmaktaydılar. Ayrıca hastahanelerde ilâç yapıldığı dolayısıyla burada bir eczahanenin varlığ 1 tespit edilmektedir. Devrin kervansaraylarında dahi küçük çapta eczahanelerin bulunduğu göz önüne alınırsa, hastahanede de olması daha tabiîdir. Ayrıca isim zikredilmemekle beraber hastahanenin düzenli çalışması için bir personelin olduğu görülmektedir. Hastahanenin bütün giderlerini karşılamak için vakfedilen bağışların ve hastahenenin düzenli bir şekilde çalışmasını sağlayan bir mütevelli tayin edilmekteydi. Adeta hastahanenin idârî işler müdürü olarak görev yapan bu mütevelli, hekim ve memur tayinlerini, ilaç yapılacak maddelerin alım satımını, hastahanenin onarımını ve artan gelirle de yeni gelir getirici kaynaklar alma gibi görevleri yüklenmişti (10)."

Yinanç (24) Sivas Darüşşifası ile ilgili yaptığı araştırmalarda bazı önemli bulgulara işaret etmektedir:

"Selçuklu devrinde hastahane olarak inşa edilen darüşşifa Osmanlı devrinde medrese haline getirilmiş, bundan sonra da Şifaiye Medresesi adını almıştır. Şimdiye kadar Sivas Darüşşifası'nın hem hastahane hem de medrese olarak inşa edildiği varsayllıyordu. Halbuki darüşşifa vakfiyesinde medreseye ait bir kayıt bulunmadığı gibi, Sivas tahrir ve evkaf defterlerinde darüşşifanın sonradan medrese haline getirildiği açıkça ifade edilmektedir. 1574 yılında 7 öğrenci ile öğrenim yapan medresenin, 1912-1913 yillarında öğrenci sayısı 500'e ulaşmışıır. Darüşşifa 1916'da I. Dünya Savaşı dolayısıyla askeri ambar olarak kullanılmıştır (24)."

Yinanç (24) aynı çalışmasının "Darüşşifa'nın Osmanlı Devrinde Vakıfları" alt başlıklı bölümünde Sivas Darüşşifası'nın Osmanlı devrinde medrese haline getirildiğini ve Şifaiye Medresesi adını aldığını bir kez daha vurguladıktan sonra şöyle devam etmektedir:

"Bundan sonra da vâkıfın şartlarına uyulmayıp medresenin hizmeti doğrultusunda vakıfta değişiklik yapılmış ve medresenin vakıfları ile görevlileri yeni duruma göre tespit ve tayin edilmiştir. Şifaiye Medresesi vakıflarının tamamı 1574 tarihli Sivas tahrir ve evkaf defterlerine kaydedilmiştir. Bu defterlerde darüşşifanın Selçuklu devrindeki vakıflarının bir kısmının Osmanlı devrinde vakıftan çıarılmış olduğu, buna karşıllı yeni köy ve mezraların vakfedildiği görülür. $\mathrm{Bu}$ hususu Selçuklu Devleti'nin yıkılmasıyla vakıf köylerin uzun süre muhtelif devletlerin sınırları içinde kalması, dolayısıyla vakıf gelirinin kesintiye uğraması ve nihayet şartların değişmiş olmasıyla izah etmek gerekir (24)."

Yinanç'ın bu tespitleri, bazı kaynaklarda gördüğümüz ve Selçuklulara ait vakıfların Osmanlı İmparatorluğu zamanında bozulmayarak aynen devam ettiği şeklinde dile getirilen bir görüşün (3) de sorgulanması gerektiğini göstermektedir. Gerçekten de ortada bir eser, bir başka deyişle bir darüşşifa vardır, ama kuruluş vakfiyesi ile sonradan düzenlenen vakfiyeleri farklı olabilir ya da yukarıdaki örnekte görüldüğü gibi, kuruluş yeni bir yapılanmaya dönüştürülebilir. Bu nedenle belgelerden yola çıkarak tarihsel tespitler yaparken, belgeler işığında var olan durumu belirlemek, genellemeler yapmaktan daha uygun olacak gibi görünmektedir. 
Vakfiyeler, tahrir ve evkaf defterleri, atama fermanları gibi yazılı belgeler binalar1 halen var olmayan ve yerleri bilinmeyen darüşşifalar ve medreseler gibi eserlerin varlığını bize haber vermektedirler. Bu duruma Kütahya hastanesi örnek olarak verilebilir. Sayılı (18) Kütahya'nın gerek ekonomik, gerek siyasi ve kültürel bakımdan önemli bir şehir olmasına dayanarak, burada bir hastane kurulmuş olmasının büyük bir olasılıkla akla geleceğini bildirmektedir. Sayılı yazısında daha önce böyle bir hastanenin varlığı hakkında bir bilgi bulunmazken, Vakıflar Genel Müdürlüğü’nde Kütahya'da bir hastanenin varlığını gösteren bazı belgelerin bulunduğunu bildirerek, bunlardan en eski kaydın da 1251 H. (1835/36) yilına ait olduğunu haber vermiştir. Sayılı incelemesinin sonunda bu hastanenin XIII. ya da XIV. yüzyılda yapılmış olmasını olasılıklı görmektedir.

Bu konuda ilginç diğer örnekler ise Aksaray Darüşşifası ve Aksaray Darüşşifa Medresesi'dir. Konyalı (25) Başbakanlık Arşivi’nde kayıtlı Kanûnî adına Aksaray Livasını tespit eden defterde Timarhane Mahallesi adiyla bir mahallenin kaydı olduğunu, yine Ankara Kadim Kayıtlar Arşivi'nde Sultan III. Murad adına yazılan Aksaray İl Yazıcı Defteri'nde bu mahallenin $B i$ marhane Mahallesi şeklinde geçtiğini belirterek, şifahanenin kitabesi ve vakfiyesinin günümüze kadar ulaşmaması nedeniyle, ne zaman ve kimin tarafından yapıldığı hakkında kesin bir hükme varmaya olanak olmadığını bildirtmektedir. Öte yandan Aksaray Darüşşifa Medresesi ile ilgili 1524 tarihli bir tayin vesikasının kaydını sunan Konyalı (25), bu tayin emrinde Kanûnînin yeni müderrise Darüşşifa Medresesi'nde vâkıfın şartlarına uygun bir şekilde hareket etmesini tavsiye ettiğini, vâkıfın adını vermediğini bildirmiştir. Bu konuda yaptığı açıklamada Darüşşifa Medresesi'nin Aksaray Darüşşifası'nın içinde mi olduğu ya da Zincirli Medresesi'nin bir ara Darüşşifa Medresesi mi olduğu konusunda açıklayıcı bir belge olmadığından da söz etmektedir.
Öte yandan Aksaray Darüşşifası hakkında oldukça ilginç bazı açıklamalar Türk Tib Taribi Arkivi dergisinde yer alan ve Konya Babalık Gazetesi 1937 y1l koleksiyonundan alınan Mimar Şehabettin (Uzluk)'un (26) "Anadoluda Selçuki Hastaneleri" yazısında bulunmaktadır. Şehabettin Bey yazıda Aksaray Darüşşifasinın enini, boyunu, yüksekliğini ve duvar kalınlı̆̆ını verirken, temellerinde büyük eksiklikler olduğunu bildirmektedir. Karamanoğulları zamanından yazılı taşı olduğunu bildirerek mimarının ise Kelük bin Abdullah'ın yetiştirmesi Hoca İbrahim bin İsmail olduğunu haber vermektedir. Zincirli Medrese'den de bahseden Şehabettin Bey, bu medresenin de mimari özelliklerini verdikten sonra; portalin üstünde "vemen yetevekkelu Alâllah" yazılı olduğunu bildirerek, bunun da ebced hesabıyla 1387 yılları olduğunu söylemekte, medresenin hastaneden de eski olduğunu haber vermektedir.

Şehabettin Bey'in haber verdiklerinden darüşşifa ile Zincirli Medrese'nin ayrı yerler oldukları sonucu çıarılabilir. Sunulan bilgiler yazının yazıldığı bu dönemde her iki yapının da kitabelerinin var olduğunu göstermektedir. $\mathrm{Bu}$ kitabelerden birisi bize darüşşifanın mimarını haber verirken, diğeri de Zincirli Medrese'nin kitabesinin tarihini haber vermektedir. Bu yazıda da Darüşşifa Medresesi ile Zincirli Medrese'nin aynı mı yoksa farklı yerler mi oldukları hakkında bir bilgi bulunmamaktadır.

Görüldüğü gibi vakıf belgeleri ve kitabeler çok önemli kayıtlardır; bize bir şifahanenin varlığını ve bir darüşşifa medresesinin varlığını haber verirlerken, çok kesin yargilara varmamiza da olanak vermemektedirler. Öte yandan vakıf kayıtları gibi kayıtların ileri incelemeleri, bu kuruluşların işleyiş̧eri ile bu tür kuruluşlarda çalışan hekimler ya da diğer çalışanlar hakkındaki bilgilerin açığa çıkmasına olanak vererek, bu konulardaki eksiklerimizi giderebilecek gibi görünmektedir.

Günümüzde var olmayan darüşşifaların saptanmaları konusunda kayıtların bulunmasının önemi kadar bu kayıtların doğru bir şekilde yorumlanmasının da önemi büyüktür. Bu konuda önemli bir örnek Konya Darüşşifaları'dır. Ünver $(4,23)$ Konya Darüşşifaları başlığı altında şu darüşşifa isimlerini vermektedir. Bunlardan birisi Kemaleddin Karatay Darüşşifası, ikincisi halkın Sakahane (şifahane) mahallesinde addettiği bimarhanedir. Bey Hekim-Tabib Ekmelüddin- mahallesinde olan şifahaneden, ki türbesinin de bu şifahane mahallesinin ardında olduğundan bahsetmektedir. Karamanoğulları döneminde var olan Şadi Bey Hastanesi adında bir hastane adı da veren Ünver, asıl büyük hastanenin banisinin Alâeddin Keykubad olduğunu bildirmektedir. Konyalı (27) ise incelediği arşiv belgelerine göre Konya’da iki hastane bulunduğunu belirterek, bunlardan birisinin Bimaristan-1 Atîk ya da Maristan-1 Atîk olarak, diğerinin de Darüşşifa olarak adlandırıldığını belirtmektedir. Konyalı (27) yaptığı incelemeler sonrası Maristan-1 Atîk'in Sultan II. Kılıçarslan tarafından yaptırıldığını kabul etmeye meyilli olduğunu belirtir. Darüşşifanın adının da Alâeddin Darüşşifası olduğunu vakıf kayıtları ve şer'i sicil defterlerine dayanarak bildirmektedir. Değerlendirmesinin sonunda, Alâeddin Keykubad Darüşşifası dışında diğer hastaneler hakkında Ünver tarafindan verilen bilginin yanlış olduğunu iddia etmektedir. Küçükdağ (28) belgelerden yola çıkarak yaptığ incelemeler sonrası Konya Alâeddin Darüşşifası, Tip Medresesi ve Mescidi'nin yerini belirlemiştir. Bayram (16) da Konya’da Kadı İzzüddin tarafından yaptırılan cami, medrese ve şifahanenin vakıf-namesinin nüshasını yayınlamıştır. Bayat (21) da bütün bunlardan sonra darüşşifalar hakkında yaptığı toplu inceleme de Konya'da bulunan darüşşifaları Maristan-1 Atîk, Alâeddin Darüşşifası ve Kadı İzzeddin Darüşşifası olarak vermektedir.

Anadolu Selçuklularından günümüze kalan darüşşifaların bazılarında kitabelerin de bulunması bu yapiların banilerini, yapım tarihlerini ve bu eserlerin 
mimarlarını da bize bildirmektedir. Sivas İzzeddin Keykâvus Darüssıhası vakfiyesinden başka kitabesi ile de önemli bir örnektir. Yapının taçkapı nişi içinde kapının üzerini dolanan Selçuklu sülüsüyle yazılmış bir satır halinde Arapça kitabe bulunur. Kitabe metninde verilen tarih $614 \mathrm{H}$. (1217/18) olup, yapının inşa tarihidir. Yapıdaki ikinci kitabe İzzeddin Keykâvus'un türbesinin inşa tarihini vermektedir. Ustanın adı da "Amele Ahmed" ve "bin bizl el merendî" olarak türbe cephesinde iki çini pano üzerinde zemin oyularak verilmiştir (1).

Bu konuda diğer bir örnek ise Divriği Turan Melek Darüşşifası'dır. Birbirine bitişik cami ve dârüşşifâdan oluşan bu kompleksin, camiini Mengüceklerin Divriği kolu hükümdarlarından Ahmed Şah, darüşşifayı da eşi Erzincan Beyi'nin kızı Turan Melek Sultan yaptırmıştır (2). Darüşşifanın taçkapısındaki nesih yazılı üç satır halindeki Arapça kitabesi darüşşifanın bânisinin adını vermektedir (1). Kitabenin Türkçesi şöyledir: "626 H. (1228/29) tarihinde Fahrü'd-dîn Behram Şah'ın kızı Allah'ın affına muhtaç Adil Melike Turan Melik bu mübarek Dârü’ş-şifầyı yaptırd. Allah kabul etsin" yazmaktadır. Darüşşifanın içinde doğu eyvanının yukarı kısmında "Amel-i Hor-Şah Ahmet Çelebi" şeklinde bu abidenin mimarının ismi de belirtilmiştir (29).

Üçüncü bir örnek ise Selçuklu vezirlerinden Pervâne Muineddîn Süleyman'ın oğlu Muhezzibüddin Ali tarafından Kastamonu'nun merkezinde yaptırılan Ali bin Süleyman Maristanıdır. Yüz elli sene önceki yangında büyük tahribata uğrayan darüşşifadan, portalin bulunduğu ön cephe ile yan duvarlarının bir kısmı kalmışıı (2). Taçkapıda Arapça kitabe metni bulunur. Yay kemerli giriş açıklığı üzerinde üç tarafta dolanan ve taşın oyulmasıyla oluşturulmuş, Selçuklu nesihiyle mimarın ve ustanın adı okunmaktadır. Mimarı Kayserli Sa’id, ustası ise Küherbaş่dır (1).

Amasya Darüşşifası İlhanlı hükümdarı Sultan Muhammed Olcayto Hüdabende'nin karısı Yıldız Hatun'un kölelerinden Anber bin Abdullah tarafından yaptırılmıştır. Mimarı bilinmeyen darüşşifanın taçkapsısındaki kitabesi Arapça olup, kapı nişini üç yönde tek satır olarak dolanmaktadır. Yapilış yilı 708 H. (1308/9)'dur (1). Hastane olmasının yanı sıra hekim yetiştiren bir kurumdur (2). Kitabenin Türkçesi şöyledir:

"Büyük sultan, en büyük hakan, dinin ve dünyanın yardımcısı Sultan Olcaytu Muhammed (Allah, onun saltanatını ve büyük hatun, büyüklerin kraliçesi Ildus Hatun'un şeref günlerini ebedî kılsın ve devletini artırsın)'in devletinin zamanında bu mübarek dârü'ş-şifâyı imar etmekle saltanatının yüceliğini muvaffak kılsın. Zayıf kul Anber bin Abdullah Allah ondan yaptıklarını kabul etsin yıl 708 (30)."

Buraya kadar sunulan kitabe örnekleri yapının kendisinin ya da bir bölümünün halen ayakta olduğu ve kitabesinin de bulunduğu darüşşifaları göstermektedir. Bundan sonra vereceğimiz örnek kitabe Çankırı Darüşşifası'na ait olup, bu kitabe bize günümüzde ayakta olmayan bir darüşşifanın varlığını kanıtlamaktadır.

Çankırı Cemaleddin Ferruh Darülafiyesi Selçuklu devlet adamlarından Sivâs Darüşşifâsı vakıflarının mütevellisi Cemâleddin Ferruh tarafindan yaptırılmıştır. Günümüze kitabesinden bir bölüm kalmıștır. Kitabe inșa tarihini 633 H. (1235) yilı olarak verirken, Atabey Cemaleddin Ferruh tarafindan yaptırıldığını bildirmektedir (1,31). Arapça olan bu kitabenin Türkçesi şöyledir:

“Bu mubarek Dârülâfiye'nin yapılmasını 633 yılı Muharrem ayında Büyük Sultan, memleketler açan, Abbasiye Halifesinin (Emirülmüminin) ortakçısı ve Keyhüsrev oğlu Alâüd-dîn Keykûbâd-Allah aziz ve mansur eylesin- devletli günlerinde kulların fakiri ve Allah'ın rahmetine muhtaç azatlı kölelerden Atabey Lala Cemâlü’ddîn Ferruhu-Allah muvafik eylesin- emretti (31)."
Öte yandan Ünver (23) de Çankırı Darüşşifası'nın şer 'iyye mahkemesi kayitlarında bulunduğunu, bulunduğu yere de timarhane mahallesi dendiğini belirtmektedir. Başbakanlık arşivinde var olan $1202 \mathrm{H}$. (1787) tarihli bir beratta "Çankırı'da kâin timarhane mescidi vakfı emanet ciheti” yazılı olduğunu belirtmektedir. Ünver (4) yine bir başka eserinde 990 H. (1582/3) tarihinde Mustafa bin Ramazan isimli bir kişinin timarhane mahallesine getirdiği su mecrasını tamir ve her mahalle için bir miktar para vakfettiğini, timarhane mahallesinin de taş mescit adı verilen mevlevihane civarı olduğundan bahsetmektedir. $\mathrm{Bu}$ örnek kitabelerin ve kayıtların birbirlerini desteklediği durumlarda elde edilen bilgilerin kesinliğe biraz daha yakın olabileceğini göstermektedir.

Bayat'ın (21) darüşşifalar üzerine olan toplu değerlendirmesinde verdiği bibliyografya taranırken üzerinde çok fazla çalışma yapilmamış bazı darüşşifa isimlerine rastlandı. Bunlardan birisi de Harput Maristan'ı idi. Ünver'in isteği ile Başar (20) tarafından yapılmış bir araştırmanın sonucunu bildiren yazı, Harput'ta bir darüşşifanın varlığını haber vermektedir. Yazı, Ardıçoğlu’nu (19) kaynak göstererek, Harput Kalesi'nin onarımı sırasında kullanılan bazı taşların aslında kitabe özelliğinde olduğu ve bunlardan birisinin de Harput Maristanı'na ait olduğunu bildirmektedir. Maristanın yapım tarihini de 626 H. (1229), Artukluların son hükümdarı Nurettin Artuk Şah dönemi olarak haber vermektedir. Ardıçoğlu'nun (19) eseri kalenin tamirine ait kitabelerin burç üzerinde olması nedeniyle tetkik için iskele kurulduğu sırada bunlardan başka, aynı burçta fark edilen başka kitabelerin de bulunduğunu bildirmektedir. Buna göre bu kitabeler 5 bloktan oluşmaktadır: Birinde tarih vardır: 626. Diğeri ustanın adını içermektedir. 1. ve 2. blokta birinci satırda: "Bismillahirrahmanirrahim haza ma tatavvaa" 3. blok 1. satırda "Biamele el-marsan ül-mübarek" 3. blok 2. satırda "El- 
melik ül-Muiz Nur üd-..” kelimelerinin okunduğunu haber vermektedir. Ardıçoğlu (19) "marsan” kelimesinden yola çıarak, marsan kelimesinin "maristan" kelimesinin muhaffefi olarak hastane demek olduğunu, bu nedenle bunun bir hastane kitabesi olduğunu söylemekte, hastanenin de büyük bir olasılıkla kalenin içerisinde yapıldığı yorumunu yapmaktadır. Bu bilgiler oldukça ilginçtir. Ardıçoğlu (19) bu kitabelerin kaybolmasını önlemek için "onları yerinden alarak önce Harput halkevine, oradan da Elazığ halkevinde teşkiline karar verilen müzeye naklettirdik" demektedir. Başar (20) ise "1957'de Alaca camiinde Harput müzesinin kurulması üzerine, kitabeler buraya naklolunarak muhafaza altına alınmışlardır. Ne yazık ki, geçen süre içinde sözü geçen kitabelerin iki bloku kaybolmuştur" haberini vermektedir. Başar (20) devamla "Müze idaresinin envanterinde No: 2 A,B,C ile kayıtlı bulunan kitabe parçalarını Harput müzesinde görmüş, fakat hazırlıksız bulunmamız sebebiyle fotoğraflarını alamamıştık" diye bildirmektedir. Bu bilgiler bizi kitabelerin nasıl korunması ve kayıt altına alınması gerektiği gibi önemli noktalara getirmektedir.

Kitabelerin bir başka özelliği bazen bunların özet vakfiyeler gibi kullanılmış olmasıdır. Köprülü (32) “..Bazı dönemlerde bazı belgelerin ve o arada vakıf işlerine ait bazı emirlerin ya da herhangi bir vakıf tesisine aid şartların taşlar üzerine kazdırılarak tespit edildiğini biliyoruz ki, zamanın tahribatına mukavemet eden bu gibi resmi vesikalar, doğrudan doğruya vakıflara aid en eski ve en itimada lâik kaynaklardır" açiklamasıyla bu konuya dikkat çekmektedir. Kütahya'da Germiyanoğlu Ya'kûb Bey (ö. 1428) imaretinin kitabe-vakfiyesinde (814 H. / 1411) tıp tarihimizi ilgilendirecek önemli bir bilgi vardır: "ve dahı anda kim haste olası olursa, ana hekim getüreler, 'ilâc itdüreler ve hekim hakkını vireler ve edviye bahâsın vireler $(2,33) . "$

\section{Sonuç ve Öneriler}

Bayat (21) Anadolu Selçuklu Dönemi darüşşifaları üzerine yaptığı toplu bir değerlendirmede "tarihi kaynaklarda Türkiye Selçukluları döneminde Mardin, Silvan, Harran, Antakya, Erzincan, Kars ve Harput'ta darüşşifaların yapıldığı kaydediliyorsa da, bunlara ait herhangi bir vesika günümüze ulaşmamıştır” diyerek, bu yazısında verdiği darüşşifalar listesine Mardin Darüşşifası'nı katmamıştır. Ünver (23) ise açıklamalarında Artukoğullarından Necmeddin Gazi'nin Mardin'de, kardeşi Emüniddin'in inşa ettirmeğe başladığı ama bitiremediği hastaneyi tamamlatarak kardeşinin ismini verdiğini ve ayrıca Silvan'da da bir darüşşifalarının bulunduğunu bildirmektedir. Mardin hastanesinin XIX. yüzyılın başına kadar işlevini sürdürdüğünü Başbakanlık Arşiv Belgelerine dayanarak bildirmektedir (23). Pek çok kaynakta Mardin'de bir darüşşifa bulunduğu bildirilmesine karşı $(1,17,23)$, Bayat (21) Mardin'de bir darüşşifa yapıldığ hakkında günümüze herhangi bir belgenin ulaşmadığını söylemesi ilginç olmakla birlikte, Bayat (2) daha sonra kaleme aldığı bir eserinde Mardin Darüşşifası'nı varlığı kesinlik kazanmış darüşşifalar listesine almıştır. Öte yanda, Konya'da bulunan darüşşifalar hakkında yapılan tartışmalar sonrası verilen bilgilerin halen sorgulanabilir olduğu da düşünülebilir. Görüldüğü gibi, bu çelişkili bilgiler incelemelerin derinleştirilmesini gerekli kılmaktadır. "Üstat dedi ki" anlayışından sıyrılarak özenli incelemelerin yapılması, bu konulardaki bazı hatalı bilgilerin düzeltilmesini de sağlayacaktır. Bu durumda gerçeğin ne olduğunu ancak ulaşılabilecek kayıtlar ortaya koyacağından, Vakıfların elindeki belgelerin tıp tarihi açısından taşıdığı önem tartışılmaz görünmektedir. Bu nedenle vakıf kayıtları özenle yeniden gözden geçirilmeli, yeni bulgular ışı̆̆ında var olan bilgi ve bulgular değerlendirilmeli, gerekirse yeniden yorumlanmalı ve bilimsel ortamlarda bilim dünyasına sunulma- lıdır. Vakıf kayıtlarının bulunmadığı durumlarda daha da önem kazanan kitabeler de önemli kayıtlardan olup, bunların korunması ve kayıt altına alınmaları da önemli görünmektedir. Bayat'ın (21) işaret ettiği gibi “..Türkiye Selçukluları dönemi Anadolu'da inşa edilen darüşşifalar hakkında yayın yapacakların bu konudaki son araştırmalar ışığında yayınlarını yapmaları gerekmektedir. Aksi takdirde birilerinin ortaya attığı yanlış görüşler devam edip gidecektir."

Tarihçi Köprülü’nün (34) vakıf kayıtları ile ilgili söyledikleri önemlidir:

"Vakıf müessesesi, orta ve yeniçağlar Türk ve İslâm dünyasını tetkik için birinci derecede mühim bir kaynaktır. İlim dünyasının kolayca erişebileceği vakıf vesikaları, yalnız vakıf müessesesini hukukî ve tarihî bakımlardan aydınlatmakla kalmayacak; tarihimizin her şubesini aydınlatabilecek yeni vesikalar elde edilmiş olacaktır. İktisadî Tarih, İçtimaî Tarih, Şehir Tarihi, İskân Tarihi, Tarihî Topografya, İdarî ve Malî Tarih, Dinî Tarih hülasa eski Türk cemiyetinin dahili bünyesini, muhtelif içtimai tabakaların hayat şartlarını, hukukî, içtimai münasebetlerini bize gösterecek bütün tarih şubeleri bundan en büyük istifadeyi temin edecektir (34).”

"O halde millî tarihimizin birçok meçhul cephelerini bize gösterecek olan bu vakıf vesikaları üzerinde sağlam bir plânla çalışmaya başlayalım. Bu vesikalar birinci derecede mühim tarihî kaynaklar olarak yalnız millî tarihimize değil, bütün dünya tarihine büyük bir hizmette bulunmuş olacaktır (34).”

Darüşşifalar özelinde ve yaptığımız işin gereği olarak bu sözlere tıp tarihimizi de katmak gerektiğini düşünüyorum. Uzun yıllar önce ve öncü üstatlarla başlayan araştırma geleneğini sürdüre- 
rek, sağlık kuruluşlarımız ve çalışanları hakkında ya da onlarla ilgili olabilecek vakıf kayıtları, mahkeme kayıtları, tapu kayıtları, atama fermanları vb. belgeleri inceleyerek ve doğru bilgilere ulaşarak yapılacak çalışmalar ve gerçeğe dayanarak ortaya konacak bilgiler muhakkak ki çok değerli olacak; geçmişimizi doğru değerlendirmemizi sağlayacağı gibi, geleceğe de gerçek bir yol gösterici olacaktır. Bu amaçla yapılacak araştırmaların multidisipliner yaklaşımla ele alınması, vakıf uzmanları, sanat tarihçileri, mimarlar, tarihçiler ve tıp tarihçileri tarafindan ortaklaşa yapılması daha doğru sonuçlara ulaşmamızı sağlayacaktır.

\section{KAYNAKLAR}

1. Cantay G. Anadolu Selçuklu ve Osmanlı Darüşşifaları. Ankara: AKDTYK Atatürk Kültür Merkezi, 1992, s. 1-8, 15-19, 45-59, 67-71.

2. Bayat AH. Tip Tarihi. İzmir: Sade Matbaa, 2003, s. 174, 177, 227-231, 251

3. Yetkin Ş. Anadoluda Selçuklu şifahaneleri. Türk Kültürü 1963;(10):23-31.

4. Ünver AS. Selçuk Tababeti XI-XIV üncü Asırlar. Ankara: Türk Tarih Kurumu, 1940, s. 47-83.

5. Terzioğlu A. Ortaçağ İslâm-Türk hastahaneleri ve Avrupa'ya tesirleri. Belleten 1970;36:121-149.

6. Buharalı E. Üç Türk hükümdarın yaptırdığı üç sağlık kurumu: Tolunoğulları, Zengiler ve Memlüklerde sağlık hizmetleri. AÜ DTCF Tarih Bölümü Tarih Araştırmaları Dergisi 2005; 25 (40):29-39.

7. Dinçer F. Kişisel görüşme, 27 Mayıs 2010.

8. Turan O. Türkiye Selçukluları Hakkında Resmî Vesikalar-Metin, Tercüme ve Araştırmalar, 2. Baskı. Ankara: Türk Tarih Kurumu Basımevi, 1988, s. 50-55.

9. Yinanç R. Kayseri ve Sivas Darüşşifaları vakıfları. Belleten 1985;48:299-307.

10. Bayat AH. Anadolu Selçuklu hastane vakfiyelerinin tek örneği olarak Sivas Darüşşifası Vakfiyesi (1. Muharrem 615 / 30 Mart 1218). Türk Kültürü 1991;29:5-19.

11. Terzioğlu A. Selçuklu hastanelerinde tıp eğitimi ile deontoloji ve Avrupa'ya tesirleri. Tarih ve Toplum 1992;18:289-299.

12. Meydan Larousse. "Vakıf veya Vakf", "Vakfiye", Cilt 12. İstanbul: Meydan Yayınevi, 1973.
13. Büyük Larousse. "Vakıf", Cilt 23. İstanbul: Milliyet gazetecilik A.Ş.

14. Türk Dil Kurumu Türkçe Sözlük, 9. Baskı. Ankara: Türk Tarih Kurumu Basımevi, 1998.

15. Meydan Larousse. "Kitabe", Cilt 7. İstanbul: Meydan Yayınevi, 1972.

16. Bayram M. Selçuklu veziri Kadı İzzeddin tarafindan düzenlenen bir vakıf-name. Ata Dergisi 1997;(7):47-53.

17. Köker AH. Selçuklu şifahaneleri. In. Köker AH, editör. Selçuklular Devrinde Kültür ve Medeniyet. Kayseri: Erciyes Üniversitesi Gevher Nesibe Tip tarihi Enstitüsü, 1992, s. $1-12$.

18. Sayılı A. Bir Kütahya hastahanesi. Belleten 1948;12:679-680.

19. Ardıçoğlu N. Harput Tarihi. İstanbul: Matbaa Teknisyenleri Basımevi, 1964, s. 58-59.

20. Başar Z. Harput Mâristanı. Dirim 46 (9):419-422, 1971

21. Bayat AH. Anadolu'da Selçuklu dönemi dârüşşfaları üzerine toplu değerlendirme. In. Eravşar O, editör. I. Uluslararası Selçuklu Kültür ve Medeniyeti Kongresi, Bildiriler, II. Cilt. Konya: Selçuk Üniversitesi Selçuklu Araştırmaları Merkezi, 2001, s. 121-148.

22. Kırzıoğlu F. Kars'ın tarihi ve Kanada Karsı. Hayat Tarih Mecmuası 1978;14(7):34-40.

23. Ünver AS. Büyük Selçuklu İmperatorluğu zamanında vakıf hastanelerinin bir kısmına dair. Vakıflar Dergisi 1938;1:17-23.

24. Yinanç R. Sivas abideleri ve vakıfları. Vakıflar Dergisi 1991;22:15-44.
25. Konyalı İH. Abideleri ve Kitabeleri ile Niğde Aksaray Tarihi, 1. Cild. İstanbul: Fatih Yayınevi Matbaası, 1974, s. 1001-1002, 1320-1321.

26. (Uzluk) Ş. Anadoluda Selçuki Hastaneleri. Türk Tib Tarihi Arkivi 1939;3:135-146.

27. Konyalı İH. Abideleri ve Kitabeleri ile Konya Tarihi. Konya: Yeni Kitap Basımevi, 1964, s. 221-236.

28. Küçükdağ Y. Konya'da Alâeddin Dârüşşifâsı, tıp medresesi ve mescidinin yeri, yapısı. Osmanlı Araştırmaları 1989;9:347359.

29. Ülgen AS. Divriği Ulu Camii ve Darüşşifası. Vakıflar Dergisi 1962;5:93-98.

30. Uzel İ(ed). Şerefeddin Sabuncuoğlu Cerrahiyyetül'l-Haniyye, Cilt 1. Ankara: AKDTYK Türk tarih Kurumu Yayınları, 1992, s. 13-14.

31. Önge Y. Çankırı Darüşşifası. Vakıflar Dergisi 1962;5:251-255.

32. Köprülü F. Vakıf müessesesi ve vakıf vesikalarının tarihi ehemmiyeti. Vakıflar Dergisi 1938;1:1-6.

33. Uzunçarşılıŏ̆lu İH. Bizans ve Selçukiylerle Germiyan ve Osman Oğulları Zamanında Kütahya Şehri. İstanbul: Devlet Matbaası, 1932, s. 79-85.

34. TC. Başbakanlık Vakıflar Genel Müdürlüğü. Türk Vakıfları Araştırma Merkezi. http:// www.vgm.gov.tr/08_KulturelFaaliyetler/005_ArastirmaMerkezi/arastirma.cfm. Erişim tarihi: 26 Mayıs 2010 